\title{
The Effectiveness of Statistics Software Training to Improve the Understanding of Quantitative Research Methodology Concepts for Students of Tadris Mathematics, Faculty of Tarbiyah and Teacher Training, UIN Maulana Malik Ibrahim Malang
}

\author{
Sulistya Umie Ruhmana Sari ${ }^{1 *}$ \\ ${ }^{1}$ Universitas Islam Negeri Maulana Malik Ibrahim Malang, Indonesia \\ *Corresponding author.Email: sulistyaumieruhmanasari@uin-malang.ac.id
}

\begin{abstract}
The research was conducted using a quantitative approach. The population used in this study were students of Tadris Mathematics of UIN Malang as many as 40 people. The purpose of this research is to see the effectiveness of the holding of statistical software training for studenst of Tadris Mathematics of UIN Malang on understanding the concept of quantitative research methodology for. The effectiveness is seen by comparing the students scores before being given statistical software training with the students scores after being given statistical software training. The comparison was carried out using the paired t test. Based on the results of the normality test, it is concluded that the pre-test and post-test data have a normal distribution. Then the results of the correlation test or the relationship between the two pre-test and post-test variables can be said that there is no relationship between the pretest variable and the post-test variable. The results of data analysis show that the significance value is 0.000 . Because the significance value of $0.000<$ the alpha value used $(0.05)$, Ho is rejected and $\mathrm{Ha}$ is accepted. This shows that there is a difference between the average of pretest and posttest scores.
\end{abstract}

Keywords: Effectiveness, Statistics Software Training, Quantitative Research

\section{INTRODUCTION}

Statistics is a branch of mathematics that specializes in studying all things related to data. According to Wikipedia, statistics is a science that studies how to plan, collect, analyze, interpret and finally present data. Statistics is a science that has been used in various fields, in the fields of natural, in social and psychological sciences, in the fields of business, and in economics and industry. Statistics are also often used in the government sector, which is the most frequent and government's routine agenda, namely the census.
In fact, we often get a lot of data to be processed and require calculations with complex statistical formulas. Processing the big data with complex statistical formula requires a high accuracy. Meanwhile, if big data are processed and uses manual data processing, there is a big chance that errors will occur in the calculation process. Improper data processing will also affect to the validity of the research results. However, the statistical application can help and make it easier to perform statistical calculations and testing. The level of accuracy of calculations using a computer is higher than manually[1]. There are several types of statistical software that are most widely used by the public, 
including Minitab, SPSS, SAS, Eviews, R, Stata, and others.

Meanwhile, research is a process to find and prove the truth of a phenomenon or fact which is carried out in a structured and systematic manner. Methods for conducting research are generally divided into qualitative and quantitative. Quantitative research methods are methods that use numerical data and emphasize the research process on measuring objective results. Therefore, the use of quantitative research methods is closely related to statistical analysis.

Based on the initial survey conducted by the author, about $40 \%$ of students of Tadris Mathematic at the Faculty of Tarbiyah and teacher training UIN Malang have the desire to conduct research using quantitative research methods, but they have a low understanding of the data analysis method used. Therefore, the authors held a statistics software application training for these students of Tadris Mathematics. Then an evaluation will be carried out, how effective the statistical software training is to improve understanding of quantitative research methods for students of tadris mathematics at the FITK for further activities.

Several previous studies have been carried out by Fadrik Adi Fahrudin of UIN Mataram who examined the effectiveness of Problem Based Learning on Creative Thinking Ability of Students of the Tadris Mathematics of UIN Mataram where the research discussed the Problem Based Learning model carried out on students of Tadris Mathematics of UIN Mataram[2]. Meanwhile, Popy Darsono of UIN Raden Intan Lampung has conducted research related to the Effectiveness of the Mind Mapping Assisted ADDIE Learning Model on the Ability of Understanding Mathematical Concepts[3]. And so far, no one has conducted research to find the effectiveness of Statistics Software Training, therefore the authors are interested in raising the theme of the Effectiveness of Statistics Software Training to Improve Understanding of Quantitative Research Methods for studets of Tadris Mathematics, Faculty of Tarbiyah and Teacher Training, UIN Malang.

\section{RESEARCH METHODS}

\section{$2.1 \quad$ Data}

The definition of data is a number that has meaning or that provides information. Data is something that has no meaning to the recipient and is still raw, so it requires some processing. Data can have the form of a state, image, sound, letter, number, language or other symbols that we can use as material to see the environment, object, event or concept[4].

\subsubsection{Data based on measurement scale}

In statistics, there are four types of data based on the measurement scale, namely nominal, ordinal, interval, and ratio. In this study, the measurement scale used is the ratio. The ratio measurement scale is a quantitative number that has absolute zero value. Absolute zero means zero which means nothing. Data centered measures for the ratio measurement scale using mean, median, and mode.

\subsubsection{Data based on the source}

Data based on the source consists of two, namely primary and secondary. Primary data is data taken directly through research and the results are accounted for by the researcher. Meanwhile, secondary data is data obtained from agencies or from previous research.

\subsubsection{Data based on the nature}

Data based on the nature consists of two, namely qualitative and quantitative data. Qualitative data is data that is presented in the form of words, sentences or pictures. Meanwhile, quantitative data is data that is presented in numerical or qualitative terms. Qualitative data is also called non-metric data, while quantitative data is called metric data. Non-metric data consists of data with nominal and ordinal measurement scales. Then the metric data consists of data with interval and ratio measurement scales.

\subsection{Descriptive Statistics}

Descriptive statistics is the field of statistics that studies how to collect, organize, and present research data. Descriptive statistics is a part of statistical science that summarizes, presents and describes data in an easyto-read form so that it provides more complete information. Descriptive statistics are only concerned with describing or providing information about a data or situation or phenomenon, in other words, only seeing a general picture of the data obtained. Descriptive statistics are methods related to collecting and presenting data so as to provide useful information. Descriptive statistics function to describe or provide an overview of the object under study through sample or population data. The data presented in descriptive statistics are usually in the form of data concentration measures[5]. One of the commonly used data center measures is the mean. Apart from being in the form of data centering measures, it can also be presented in the form of one of which is the Pareto diagram and table. The following is an explanation of the mean, pareto diagram, and table. 


\subsubsection{Table}

A table is a list containing an overview of a number of facts and information. The shape is in the form of columns and rows. Tables are visual aids that serve to explain a fact or information in a concise, clear, and more interesting manner than words. Presentation of information using tables is easier to read and summarize. Tables that are often used are frequency distribution tables, relative frequency distribution tables and contingency tables for qualitative data with many categories in rows and columns[6].

\subsubsection{Mean}

The average is denoted by an $\mathrm{x}$ marked on it $(\overline{\boldsymbol{x}})$ or so-called ( $\mathrm{x}$ bar). The mean of a population is denoted by $\mu$, while for the sample it is denoted by $\mathrm{x}$. If you have variable $X$, namely $X_{1}, X_{2}, X_{3}, \ldots, X_{N}$ as a result of observations or observations $N$ times, then the population mean is described in Equation 1 as follows [7].

$$
\mu=\frac{\sum_{i=1}^{N} x_{i}}{N}
$$

Note :

$$
\begin{aligned}
& \mu \text { : average of } \mathrm{N} \\
& x_{i}: \text { the value of variable } \mathrm{i} \\
& \text { I and } \mathrm{N} \text { is a lot of variable }
\end{aligned}
$$

\subsubsection{Standard Deviation}

Variance and standard deviation (standard deviation) are the most frequently used measures of statistical data variance (variation). The standard deviation (standard deviation) is the square root of the variance, on Equation 2 .

$$
s=\sqrt{s^{2}}
$$

The basis for calculating variance and standard deviation is the desire to determine the diversity of a data set. One way to determine the diversity of a data set is by subtracting the mean of each data value from that group of data, then adding up all the results. However, this method cannot be used because the result will always be 0 .

Therefore, the solution so that the value does not become 0 is by squaring each reduction in the data value and the average for the data group, then adding it. The sum of squares will always be positive, such on Equation 3

$$
\sum_{i=1}^{n}\left(x_{i}-\bar{x}\right)^{2}>0
$$

The variance value is obtained from dividing the sum of squares by the data size (n), as described on Equation 4 .

$$
s^{2}=\frac{\sum_{i=1}^{n}\left(x_{i}-\bar{x}\right)^{2}}{n}
$$

However, in practice, the variance value is biased to predict population variance. By using this formula, the population variance value is greater than the sample variance.

Therefore, in order not to be biased in estimating population variance, $n$ as the divisor of the sum of squares is replaced by $n-1$ (degrees of freedom) so that the sample variance value approaches the population variant. Therefore the sample variant formula becomes:

$$
s^{2}=\frac{\sum_{i=1}^{n}\left(x_{i}-\bar{x}\right)^{2}}{n-1}
$$

The resulting variance value is a quadratic value. If the unit of average value is gram, then the value of variance is gram squared. To uniform the unit values, the variance is squared so that the result is the standard deviation (standard deviation).

$s=\sqrt{\frac{\sum_{i=1}^{n}\left(x_{i}-\bar{x}\right)^{2}}{(n-1)}}$

To simplify the calculation, the formula for variance and standard deviation (standard deviation) can be derived as follows[8].

The formula of variance :

$s^{2}=\frac{n \sum_{i=1}^{n} x_{i}^{2}-\left(\sum_{i=1}^{n} x_{i}\right)^{2}}{n(n-1)}$

The formula of standard deviation :

$s=\sqrt{\frac{n \sum_{i=1}^{n} x_{i}^{2}-\left(\sum_{i=1}^{n} x_{i}\right)^{2}}{n(n-1)}}$

\subsubsection{Standard Error of Mean (SE mean)}

Standard error can show how the level of fluctuation of the estimator or statistic. Standard error can also be interpreted how accurate the estimator is in estimating parameters. The formula used to calculate the standard error of the mean is as follows[9].

$S E($ mean $)=\frac{\text { Deviation Standard }}{\sqrt{n}}$ 
Standard error can be applied in two ways:

1. The estimation value or statistics divided by the estimator's standard error will show whether the statistics are zero, then the value is compared with the value in the $t$ distribution table. Based on some literature, the ratio of the estimated value or statistic to the standard error is called the Wald Test, or in some applications it is called the t-test.

2. Standard error as part of a confidence interval. For large samples, $95 \%$ confidence interval is obtained from $1.96 \mathrm{x}$ estimator standard error. The standard error used for the confidence interval is the standard error mean (SE (mean), with the following conditions:
a. $90 \% \mathrm{CI}$-> mean +/- $1.64 \mathrm{SE}$ (mean)
b. $95 \% \mathrm{CI}->$ mean $+/-1.96 \mathrm{SE}$ (mean)
c. $99 \% \mathrm{CI}->$ mean $+/-2.58 \mathrm{SE}$ (mean)

\subsection{Normality Test}

The normal distribution test is used to determine whether the residuals follow the normal distribution or not. The test used is the Kolmogorov Smirnov test with the following hypotheses [10]:

$\mathrm{H}_{0}: F_{0}(x)=F(x)$ (Residual are normally distributed)

$\mathrm{H}_{1}: F_{0}(x) \neq F(x)$ (Residual are not normally distributed)

The test statistics used are as follows.

$D=\operatorname{Sup}_{x}\left|F_{0}(x)-S_{n}(x)\right|$

Decision : Reject $\mathrm{H}_{0}$ if

$|D|>q_{(1-\kappa)}$ where $\Psi_{(1-\kappa)}$ taken according to the

Kolmogorov-Smirnov table.

\subsection{Paired Sample t-Test}

Dependent sample t-test or often termed Paired Sample t-test is a type of statistical test that aims to compare the mean of two paired groups[11]. Paired sample can be defined as a sample with the same subject but experiencing two different treatments or measurements, namely measurements before and after treatment. The paired t-test requirements include: data is normally distributed, the two data groups are dependent (interconnected / paired), and the types of data used are numeric and categorical. The t-test formula used for paired samples is as follows[12].

$$
t=\frac{\bar{x}_{1}-\bar{x}_{2}}{\sqrt{\frac{s_{1}^{2}}{n_{1}}+\frac{s_{2}^{2}}{n_{2}}-2 r\left(\frac{s_{1}}{\sqrt{n_{1}}}\right)\left(\frac{s_{2}}{\sqrt{n_{2}}}\right)}}
$$

Note :

$\bar{x}_{\mathrm{I}}$ : Average of sample 1

$\bar{x}_{2}:$ Average of sample 2

$s_{1}:$ Standard deviation of sample 1

$s_{2}:$ Standard deviation of sample 2

$s_{1}^{2}$ : Varians of sample 1

$s_{2}^{2}$ : Varians of sample 2

\subsection{Approaches and Procedures of Research}

One of the most important things in conducting research activities is determining the research approach to be used. This research was conducted using a quantitative approach, namely using a research method based on the philosophy of positivism. The population used in this study were 40 students of Tadris Mathematika who covered the Quantitative Research Methodology course. Because the population is too small, this population will also be the sampling unit in this research.

Based on the method of research, the researcher make an event or situation exist, then observed the consequences, so this research is a quasi-experimental. Experimental research is a way to find a causal relationship between two factors that are deliberately caused by the researcher and then in the research process, observations are made to determine the differences that occur in the experiment. Of course, this difference is the result of comparing the two factors.

This study tested the differences in students scores taken before receiving statistical software training (pretest) and students scores taken after receiving statistical software training (post-test). To analyze the differences of each variable using the paired sample t-test test method because the researcher wanted to know whether there was a difference before and after the statistical software training was carried out on understanding the concept of quantitative research methodology in students' of Tadris Matematika UIN Malang.

\section{RESULT}

Tests were carried out using the paired t test and the results are presented in the Table 1.

Table 1. Tests of Normality

\begin{tabular}{|l|c|c|c|c|c|c|}
\hline \multirow{2}{*}{} & \multicolumn{3}{|c|}{ Kolmogorov-Smirnov ${ }^{\mathrm{a}}$} & \multicolumn{3}{|c|}{ Shapiro-Wilk } \\
\cline { 2 - 7 } & Statistic & df & Sig. & Statistic & df & Sig. \\
\hline Pre_Test & .183 & 40 & .062 & .869 & 40 & .340 \\
Post_Test & .203 & 40 & .540 & .845 & 40 & .110 \\
\hline
\end{tabular}

a. Lilliefors Significance Correction 
Based on the results of the normality test, it can be seen that with the Kolmogorov Smirnov method the significance value of pretest is 0.062 and the significance value of post test is 0.540 . This value is greater than 0.05 (the alpha value used), so it can be concluded that the pre-test and post-test value data have a normal distribution. Meanwhile, the other method of normality test named Shapiro Wilk also obtained significance value of pretest 0.340 and significance value of post test is 0.110 which is more than 0.05 , so it can also be concluded that the pre-test and post-test value data have a normal distribution. Thus, the requirements or assumptions for normality of the paired sample t test have been fulfilled.

In the Figure 1 and Figure 2, a graph will be presented that explains the descriptive statistics of the pre-test and post-test variables used.

From the Figure 1 above, it can be seen that the pretest score of Mathematics Tadris students before being given statistical software training is below 70 . From the pretest data, it is known that the highest pretest value is 65 while the lowest pretest value is 50 . While in Figure 2 we can see that the value The post-test obtained by Tadris Mathematics students after receiving statistical software training is quite increasing. The highest posttest score obtained was 88 , while the lowest posttest score obtained was 80 .

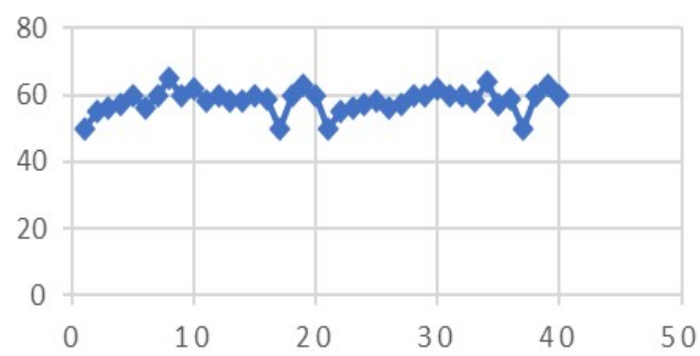

Figure 1. Pretest value of Tadris Mathematics Students

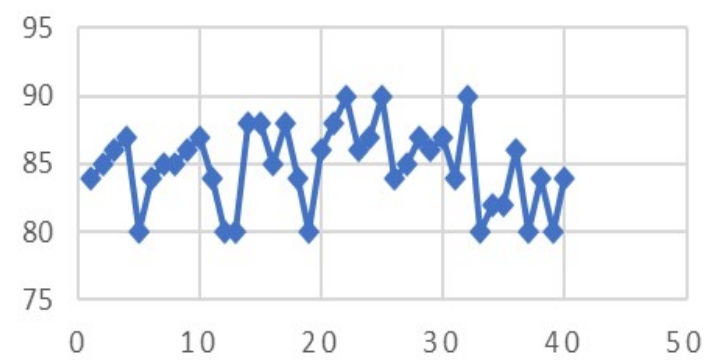

Figure 2. Posttest value of Tadris Mathematics Students

Furthermore, a more complete description of the descriptive statistics of the variables used is presented in the Table 2 .
Table 2. Paired Samples Statistics

\begin{tabular}{|c|c|c|c|c|}
\hline & Mean & $\mathrm{N}$ & $\begin{array}{l}\text { Std. } \\
\text { Deviation }\end{array}$ & $\begin{array}{l}\text { Std. Error } \\
\text { Mean }\end{array}$ \\
\hline Pair 1 Pre_Test & 58.3750 & 40 & 7.63826 & 1.20771 \\
\hline Post_Test & 84.8500 & 40 & 3.15050 & .49814 \\
\hline
\end{tabular}

In the output above, it is known that the summary of descriptive statistics results from the two variables used, namely the pretest and posttest score. The pre-test score is known to have an average of 58.37. Meanwhile, the post-test score is known to have an average of 84.85 . The number of students used in the study was 40 people. Visually, the comparison of the average pretest and posttest scores can be seen in the Figure 3.

Because the pre-test average score obtained was 58.37, meaning it was less than the post-test average score of 84.85 , then descriptively there was a difference in the average between the pre-test and post-test. Furthermore, to prove whether the difference is real (significant) or not, then the next output can be seen.

Table 3 shows the results of the correlation test or the relationship between the two variables pre-test and posttest. Based on the results of the correlation test, it is known that the correlation coefficient value is 0.147 with a significance value of 0.364 . Because the significance value of $0.364>$ the alpha value used $(0.05)$, it can be said that there is no relationship between the pretest and posttest variables.

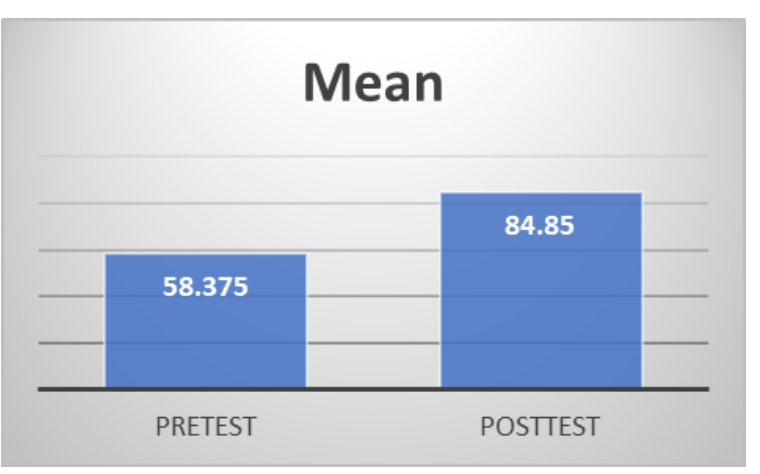

Figure 3. Comparison mean of pre test and post test.

Table 3. Paired Samples Correlations

\begin{tabular}{|ll|l|c|l|}
\hline & $\mathrm{N}$ & Correlation & Sig. \\
\hline Pair 1 Pre_Test \& Post_Test & 40 & .147 & .364 \\
\hline
\end{tabular}




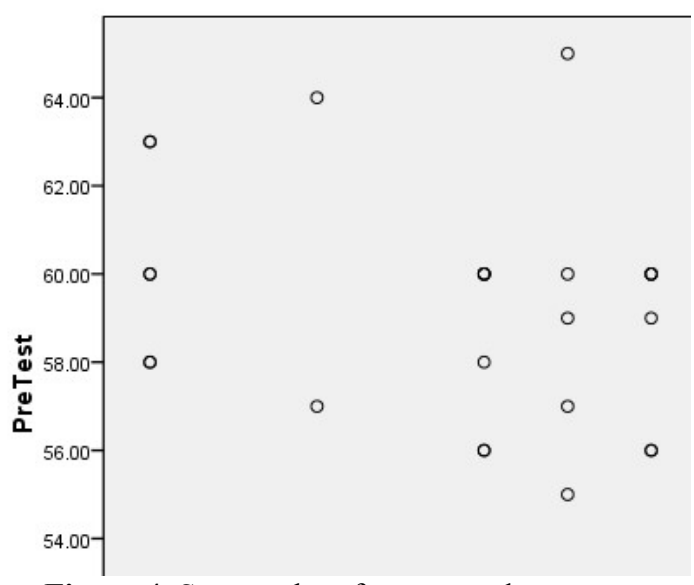

Figure 4. Scatter plot of pretest and post test

\section{Table 4. Paired Samples Test}

\begin{tabular}{|c|c|c|c|c|c|c|c|c|}
\hline & \multicolumn{5}{|c|}{ Paired Differences } & \multirow[b]{3}{*}{$\mathrm{t}$} & \multirow[b]{3}{*}{ df } & \multirow{3}{*}{$\begin{array}{l}\text { Sig. } \\
(2- \\
\text { taile } \\
\text { d) }\end{array}$} \\
\hline & \multirow{2}{*}{$\begin{array}{l}\mathrm{Mea} \\
\mathrm{n}\end{array}$} & \multirow{2}{*}{$\begin{array}{l}\text { Std. } \\
\text { De } \\
\text { viat } \\
\text { ion }\end{array}$} & \multirow{2}{*}{$\begin{array}{c}\text { Std. } \\
\text { Erro } \\
\mathrm{r} \\
\text { Mea } \\
\mathrm{n}\end{array}$} & \multicolumn{2}{|c|}{$\begin{array}{l}95 \% \text { Confidence } \\
\text { Interval of the } \\
\text { Difference }\end{array}$} & & & \\
\hline & & & & Lower & Upper & & & \\
\hline $\begin{array}{l}\text { Pre_Te } \\
\text { st - } \\
\text { Post_T } \\
\text { est }\end{array}$ & $\begin{array}{c}- \\
2.64 \\
750 \\
\text { E1 }\end{array}$ & $\begin{array}{c}7.8 \\
216 \\
9\end{array}$ & $\begin{array}{l}1.23 \\
672\end{array}$ & -28.97650 & -23.97350 & $\begin{array}{c}- \\
21.4 \\
07\end{array}$ & 39 & .000 \\
\hline
\end{tabular}

Ho: There is no difference between the average of pre test and post test

$\mathrm{H}_{1}$ : There is an average difference between the averager of pre test and post test

Apart from using correlation testing, a scatter plot can also be used to detect whether there is a correlation between the variables used. The picture above shows the points that spread out from one another, indicating that the pretest and post-test variables are not correlated with each other so that further testing can be carried out.

Based on the table above, it is known that the significance value is 0.000 . Because the significance value of $0.000<$ the alpha value used (0.05), Ho is rejected and $\mathrm{Ha}$ is accepted. So it can be concluded that there is an average difference between the pretest and post test scores.

\section{CONCLUSION}

From the results of the research conducted, it was found that there was an average difference between the pretest and posttest scores. In addition, the average value of score after statistical software training was also obtained which increased significantly compared to the average value of score after statistics software training. This indicates that the statistics software training is very effective in improving students' understanding of quantitative research methodology specially for students of Tadris Matematika UIN Malang.

\section{REFERENCES}

[1] W. E, Ronald, Pengantar Statistika, 3rd ed. Jakarta: PT Gramedia Pustaka Utama, 1995.

[2] Fahrudin, Fadrik, and Adi, "Efektivitas Problem Based Learning Terhadap Kemampuan Berpikir Kreatif Mahasiswa Program Studi Tadris Matematika UIN Mataram. Jurnal Teori dan Aplikasi Matematika," (JTAM), 1(1) (2017) 4148, DOI: https://doi.org/10.31764/jtam.v1i1.185

[3] P. Darsono, "Efektivitas Model Pembelajaran ADDIE Berbantu Mind Mapping terhadap Kemampuan Pemahaman Konsep Matematis. Skripsi.," Skripsi, 2018.

[4] A. Suharsimi, Prosedur Penelitian suatu Pendekatan Praktis. Jakarta: Rineka Cipta, 2000.

[5] R. Peck and C. Olsen, Introduction to Statistics and Data Analysis, 4th ed. MA, Boston: Brooks/Cole, 2012.

[6] Sugiyono, Statistika Untuk Penelitian. Bandung: Alfabeta, 2015.

[7] Sudjana, Metode Statistika. Bandung: Tarsito, 1992.

[8] Sudjana, Metode Statistik. Jakarta: Erlangga, 1996.

[9] A. Irianto, Statistik Dasar dan Aplikasinya. Jakarta: Kencana Prenada, 2008.

[10] N. Iriawan and A. S.P, Mengolah Data Statistik dengan Mudah Menggunakan Minitab 14. Yogyakarta: Penerbit Andi, 2006.

[11] A. Sudijono, Pengantar Statistik Pendidikan. Jakarta: PT Raja Grafindo Persada, 2008.

[12] Sugiyono, Metode Penelitian Kuantitatif, Kualitatif, dan R\&D. Bandung: Alfabeta, 2011. 